\title{
DOES THE LENGTH OF STATION RECORD INFLUENCE THE WARMING TREND THAT IS PERCEIVED BY MONGOLIAN HERDERS NEAR THE KHANGAI MOUNTAINS?
}

\author{
¿Puede la disponibilidad temporal de datos determinar \\ el calentamiento percibido por las tribus nómadas de mongoles \\ cerca de las montañas Khangai?
}

N. B. H. VEnABLE ${ }^{1}$, S. R. FASSNAChT ${ }^{1}$, G. AdYABADAM ${ }^{2}$, S. TumenJARGAL ${ }^{1,3}$, M. FERNÁNDEZ-GimÉNEZ ${ }^{4} \&$ B. BATBUYAN ${ }^{5}$

1 Watershed Science, Colorado State University, Fort Collins Colorado 80523-1476 USA 2 Institute of Meteorology and Hydrology, Khudaldaany Gudamj-5, Ulaanbaatar-210646 Mongolia 3 Ministry of Nature, Environment and Tourism Mongolia, Government Building-2, United Nation's Street-5/2, Ulaanbaatar-210646 Mongolia

4 Rangeland Science, Colorado State University, Fort Collins Colorado 80523-1472 USA

5 Center for Nomadic Pastoralism Studies, P.O. Box 361, Ulaanbaatar-210620 Mongolia

\begin{abstract}
Temperatures changes can be difficult to infer from changes in vegetation patterns or other ecological changes, yet warming can be inferred through changes in the habits of people who live in close connection with their natural environment. Herders near the Khangai Mountains of central Mongolia have perceived a warming trend in recent years. Since it is difficult to determine the exact time period over which perceived warming has occurred, we examined the statistical difference in changes based on the length of data and the specific period of record used in the analysis. We used temperature data from five meteorological stations for up to 50 years (1961-2010). We examined varying lengths of record from 15 to 50 years with varying start periods (1961 through 1986), based on the length of record. We found that the most statistically significant changes occurred for the longest time periods and for the annual average minimum temperatures. We also found that one very cold winter, in particular 2009-2010 decreased the warming trend and for shorter periods of record reduced the statistical significance.
\end{abstract}

Keywords: Climate change, warming, Mongolia, statistical significance, herder perceptions. 
RESUMEN.- Los cambios de temperatura pueden ser difíciles de inferir a partir de los cambios en los patrones de vegetación $u$ otros cambios ecológicos. Sin embargo, el calentamiento se puede inferir a través de cambios en los hábitos de las personas que viven en estrecha relación con su entorno natural. Los pastores de las montañas de Mongolia central, cerca deKhangai, perciben una tendencia hacia el calentamiento en los últimos años. Ya que resulta difícil determinar el período de tiempo exacto durante el que se ha producido el calentamiento, se analizó la diferencia estadística de los cambios en función de la longitud de los datos y el período de registros utilizado en el análisis. Hemos utilizado los datos de temperatura de cinco estaciones meteorológicas con 50 años de registros (1961-2010). Se examinaron diferentes longitudes de registro (de 15 a 50 años) con periodos de inicio diferentes (1961 a 1986). Se comprobó que los cambios estadísticamente más significativos se registran en los períodos más largos y considerando las temperaturas mínimas medias anuales. También se encontró que un invierno muy frío, en particular (2009-2010) disminuyó la tendencia al calentamiento.

Palabras clave: Cambio climático, calentamiento, Mongolia, significación estadística, percepción de los grupos nómadas.

\section{Introduction}

Mongolia is a country known for its vast rangelands. Over $83 \%$ of the country is dominated by this type of land cover/use (Angerer et al., 2008). Recent threats to rangeland health include changes in the traditional nomadic use and management of pastureland, increasing pressure from changes in livestock numbers and composition of herds, and desertification (Angerer $e t$ al., 2008; Dagvadorj, 2010). Other environmental threats include increasing pollution from urban expansion, mining, and climate change (Dagvadorj, 2010).

Steppe vegetation condition is critical to herder livelihoods. Climate variability has altered vegetation (e.g. Yu et al., 2003; Angerer et al., 2008); specifically plant production has been limited by temperature and water supply changes (Yu et al., 2003). These changes are particularly critical in mountain steppe areas which provide highly productive forage for grazing livestock and a source of water supply for more arid desert steppe rangelands downstream (Angerer et al., 2008; Fassnacht et al., 2011).

The water supply for most herders and smaller communities comes from resources that are influenced by climate variability. Approximately 36 percent of the country's population relies on water from shallow groundwater wells and 10 percent rely on water from rivers, with the remainder of the popula- 
tion using municipal water supplies derived mainly from groundwater (Dagvadorj, 2010). Access to these resources is critical for the daily needs of pastoralists, including their livestock. Herders have reported diminished volumes in lakes and rivers and lowering groundwater levels (Fassnacht et al., 2011). These decreases may be linked to a variety of factors such as irrigation and agriculture needs, mining, and climate changes (Dagvadorj, 2010).

Many of Mongolia's rivers flow from headwaters in the country's mountain ranges, including the Khangai Range in the west-central region. Between 50 and 75 percent of the country's annual runoff is derived from the mountains, mostly as rainfall, and the mountains contribute a significant portion of the groundwater baseflow that has a relatively short residence time (Dagvadorj, 2010). Precipitation in Mongolia is spatially variable by elevation and latitude, with about $50 \mathrm{~mm}$ falling annually on Gobi desert regions to 400 $\mathrm{mm}$ in northern mountain regions (Davagadorj, 2010). It is characterized by relatively intense rainfall events with most of the precipitation occurring between April and September (Davagadorj, 2010). Due to this spatial variability, trends in precipitation are not regionally consistent. Precipitation amounts and trends can vary significantly from station to station, especially in the more arid regions of the country (Batima et al., 2005; Jamiyansharav, 2010).

Climate changes, such as variations in precipitation amounts and the occurrence of precipitation, may be inferred by changes in vegetation patterns or other ecological changes. It is more difficult to quantify changes in temperature. However, temperature changes, such as warming through an increase in minimum temperatures, can be inferred through changes in the habits of people who live in close connection with their natural environment (Alexander et al., 2011).

Temperature trends play an indirect but critical role in the water budget, by affecting evapo-transpiration, precipitation timing and distribution, and / or phase of precipitation. Potential evapo-transpiration exceeds precipitation throughout Mongolia, and increasing temperatures may exacerbate this effect (Dagvadorj, 2010). In the drier steppe regions, early season warming raises evapo-transpiration rates delaying the onset of spring green up, especially when rains are delayed, increasing the risk of rangeland degradation (Yu et al., 2003; Jamiyansharav, 2010). For those areas with streamflow reliant on mountain snowmelt, changes in precipitation phase can affect the seasonal timing of streamflow (Barnett et al., 2005a). Therefore, the examination of temperature changes and trends is necessary to understand changes in hydrology and other resources. 


\subsection{Mongolian Temperature Regimes}

Mongolia has a four-season climate with hot summers and long cold winters. Fluctuations in temperature from season to season, from day to day, and even over a single day can be great. Minimum temperatures can be colder than -52 degrees Celsius and maximums can be warmer than 43 degrees Celsius (Fassnacht et al., 2011). Periods of extended heat and drought combined with subsequent long periods of cold and winter storms result in $d z u d$ (winter disaster) events that have caused large animal and even some herder mortality, loss of billions of dollars, and have severely impacted herder's livelihoods (Angerer et al., 2008; Dagvadorj, 2010; Marin, 2010).

Our climate is changing, and global temperature trends are well-documented (e.g. Solomon et al., 2007; Hansen et al., 2010). Indices of temperature extremes for central and southern Asia suggest that there is a decrease in the diurnal temperature ranges, and an increase in the number of warm nights/days for the period from 1961 to 2000 (Klein Tank et al., 2006). Temperatures in Mongolia follow this trend, with warming recorded across the country (Batima et al., 2005; Jamiyansharav, 2010). Central Mongolia has experienced long-term temperature increases of 2 to 4 degrees Celsius per century (Jamiyansharav, 2010). Some potential problems for pastoralists due to this warming include an increase in drought conditions, rapid warming then re-freezing periods in winter leading to ice-crusted rangeland, and possibly an increasing recurrence of $d z u d$ (Batima et al., 2005; Davgadorj, 2010).

Global and large regional trends vary from local data gained from individual weather stations (Pielke et al., 2002). In Mongolia, most long-term meteorological stations are located at an aimag (province) center or occasionally at a soum (county) center, so each station typically represents approximately 100,000 $\mathrm{km}^{2}$. Temperature and the magnitude of trends are expected to vary from location to location due to spatial heterogeneity of landscape characteristics and seasonality. For example, in a study of data from 17 Mongolian meteorological stations, annual winter maximum temperatures increased at 14 stations, but decreased at three others (Jamiyansharav, 2010). The indigenous climate knowledge of pastoralists, especially nomadic people, may help bridge the spatial gap between local, point-collected weather data and the influence of large regional trends (Marin, 2010).

Since changes in resource availability are of utmost importance to pastoralists (Batima et al., 2005), surveys have been conducted to collect indigenous knowledge covering a broad range of climatic change topics and events, including extremes in precipitation, drought, and winter storms (Marin, 2010; Fassnacht et al., 2011). These surveys describe changes in Mongolian herder lifestyle as they have attempted to adapt to environmental changes (Marin, 
2010), and they provide context for meteorological data analyses (Fassnachtet al., 2011).

\subsection{Herder Observations}

Temperature changes over the past decades observed by herders were referenced to changes in seasonal extremes. These were exemplified by questions about warmer and/or cooler days and nights, and the onset of seasonal changes such as snowmelt. Specific statements from surveys in 2010 included that summer days seemed hotter yet summer nights were cooler, and winters seemed warmer than those in the past (Fassnacht $e t$ al., 2011). Recent surveys in 2011 in Bayankhongor aimag suggested that spring temperatures were cooler than in the past but that snow amounts had decreased with earlier melting. One herder commented that there was a lot of snow this year (winter of 2010-2011), but another mentioned that snowmelt patterns have "changed a lot" compared to 20 years ago. Though some herders in the recent surveys perceived that winters now were cooler than in the past, one commented that, "winter is like fall-no real winter." This observation is consistent with those from previously conducted surveys. The herders have observed temperature changes, but how far back in time is their period of reference and how does a variable period of record influence the station-based trends?

This paper aims to determine how the significance and rate of temperature trends are affected by the duration of the record, i.e., number of years, and the specific period of record, i.e., the start and end years. The available period of instrumented record will be used for each station. An individual extreme event is examined to determine if it will alter the statistical period of record analysis. Specifically, it is asked whether a single cold winter will reduce the trend and/or statistical significance of increasing temperature.

\section{Study Areas}

This study examines local scale temperature variability and focuses on stations in three aimags in central Mongolia that represent both the mountain steppe and desert steppe regions. The Khangai Mountains divide the aimags; Arkhangai is to the north, Bayankhongor is south, and Uvurhangai is located to the east. Five meteorological stations are used: Erdenemandal and Tsetserleg (Arkhangai aimag), Arvaikheer (Uvurkhan-gai aimag), and 
Bayankhongor and Horiult (Bayankhongor aimag) (Figure 1). The three northern-most stations are in the mountain steppe of the Khangaimountains, Arvaikheer is in a more arid eastern edge of the mountain region while Horiult is in the desert steppe. The Erdenemandal and Tsetserleg stations are associated with Ikhtamirsoum, while Bayankhongor and Horiult are associated with Jinstsoum, as presented in the herder surveys by Fassnacht et al. (2011).

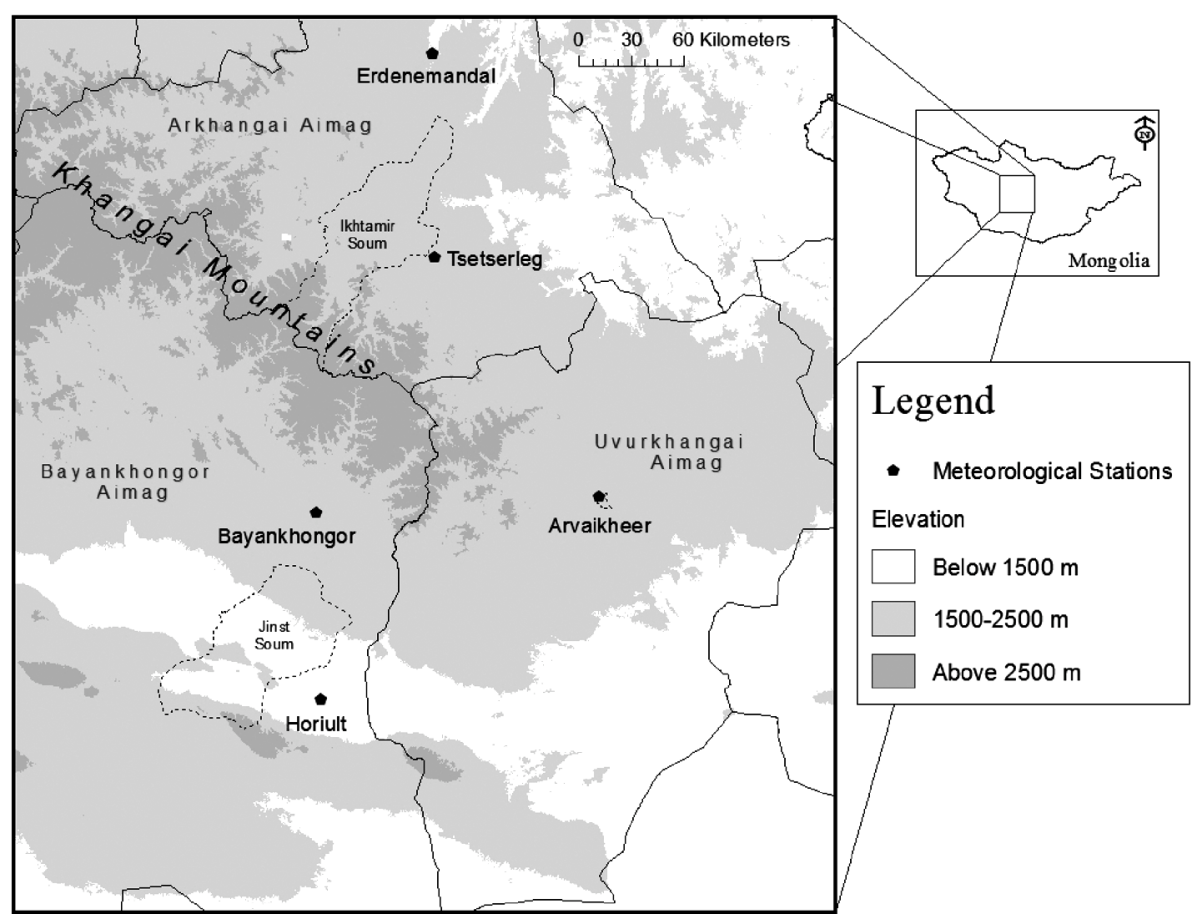

Figure 1. Map of study locations. Figura 1. Mapa de los lugares de estudio.

\section{Methods}

Meteorological data for this study were collated from two sources. Daily minimum and maximum temperature data for the Erdenemandal, Tsetserleg, Bayankhongor, and Horiult stations were obtained from the Mongolian Institute of Meteorology and Hydrology <http://www.icc.mn/Meteoins/ 
index.html>. The longest length of record was 50 years (1961-2010) for Tsetserleg station, with a similar length of record for Erdenemandal (started in 1964) and Bayankhongor (started in 1963). Data collection at Horiult started in 1976. The Arvaikheer temperature data were obtained from the Global Historical Climatology Network of the National Climatic Data Center managed by the United States National Oceanic and Atmospheric Administration $<$ http://www.ncdc.noaa.gov/ghcnm/>. There were substantial gaps in the daily maximum temperature data at Arvaikheer so only the minimum temperature data were used. Continuous data were available from 1969 through 1998 (Figure 2).

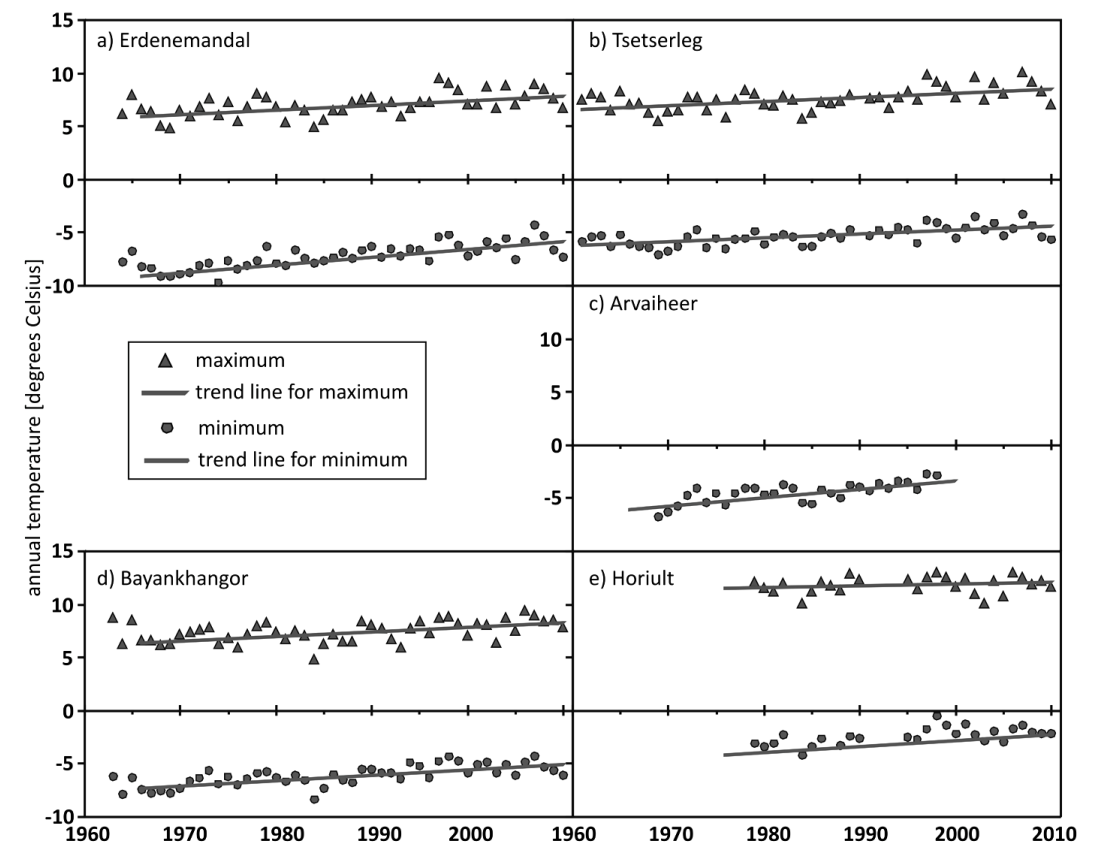

Figure 2. Annual maximum and minimum temperatures for the five meteorological stations.

Figura 2. Temperaturas máximas y minimas anuales para las cinco estaciones meteorológicas.

Annual average minimum and maximum temperatures were computed from daily data when there were less than 15 days of missing data. Typically periods of missing data were continuous and a month or more in duration. These temperature time series were analyzed using the non-parametric Mann-Kendall test for a monotonic increasing or decreasing trend with slope 
estimates or rates of change in degrees per century derived from the nonparametric Sen's method. The Mann-Kendall test determines the significance level of the change and is often reported at the 0.1, 1, 5 and $10 \%$ levels. For this study 1, 5 and $10 \%$ significance levels are reported. As these methods are non-parametric, they allow for missing values, are robust with regards to not being biased by outliers, and the data do not need to conform to any particular type of distribution (Gilbert, 1987).

To assess the significance of trends of different record lengths and time periods, calculations were run for record lengths of 50 to 15 years at decreasing five year intervals. Time periods analyzed ranged from the longest record of 1961 to 2010 to the shortest period of 1996 to 2010. The length of record analyzed and time period were dependent upon the data available. These station-based analyses were performed in light of local traditional knowledge. Quantitative hydro-climate surveys and open ended discussion were conducted with herders prior to and during the summer of 2010 (Fassnacht et al., 2011). Herders with at least 14 years of experience in the field ranging in age from 30 to 78 years of age were asked to provide perceptions of climate change over the last 20 years. Temperature changes were assessed through examination of changes in seasonal conditions and length/timing of seasons (Fassnacht et al., 2011).

Very cold winters in Mongolia are one type of extreme winter event called a $d z u d$ (Begszuren et al., 2004). The winter of 2009-2010 was quite cold in the area of the Khangai Mountains in Mongolia (Fernandez-Gimenez et al., 2011). Thus we compared the statistical analysis up to 2010 to the same length of record shifted two years earlier, i.e., up to 2008, to examine how the cold $d z u d$ of 2009-2010 changed the station analysis.

\section{Results}

The most significant trends were for the daily minimum temperatures (Table 1). These increasing trends were generally warmer (more) for the minimum than the maximum temperatures. The average temperatures (not shown) were statistically a combination of the minimum and maximum temperatures. Overall, the warming trend of longer time periods and including the more recent years (up to 2010) were the most statistically significant and often this warming trend was greater (Table 1).

Tsetserleg station has the longest records, and it exhibited highly significant changes, at the 0.001 statistical significance level (not shown), for lengths of record from 30 to 50 years. Erdenemandal followed a similar pattern with highly significant trends from 25 to 45 years, with one period of 20 years 
DOES THE LENGTH OF STATION RECORD INFLUENCE THE PERCEIVED WARMING TREND

being highly significant from 1981 to 2000. Trends at Bayankhongor were also highly significant from lengths of 30 to 40 years. For stations with shorter lengths of record, only the longest periods of 35 years at Horiult and 30 to 35 years at Arvaikheer were highly significant (Table 1).

Table 1. Rates of temperature change for annual i) maximum and ii) minimum temperatures in degrees Celsius per century as a function of length of record and period (start-end years) of record. Significant rates are presented with three significant figures and are in italics for $10 \%$ significance, in italics and underlined for $5 \%$ significance, and in italics, underlined and bold for $1 \%$ significante. Non-significant rates are report with one significant figure. Years with no data are represented as $\mathrm{N} / \mathrm{A}$.

Tabla 1. Tasas de cambio de la temperatura anual i) máximas y ii) mínimas en grados centígrados/siglo como una función de la longituud de registro y el periodo de registro. Las tasas significativas se presentan con tres cifras significativas, en cursiva para el $10 \%$ de significación, en cursiva y subrayado para el $5 \%$ de significancia, y en cursiva subrayado y en negrita para el $1 \%$ de significación. Los años sin datos se representan como N/A.

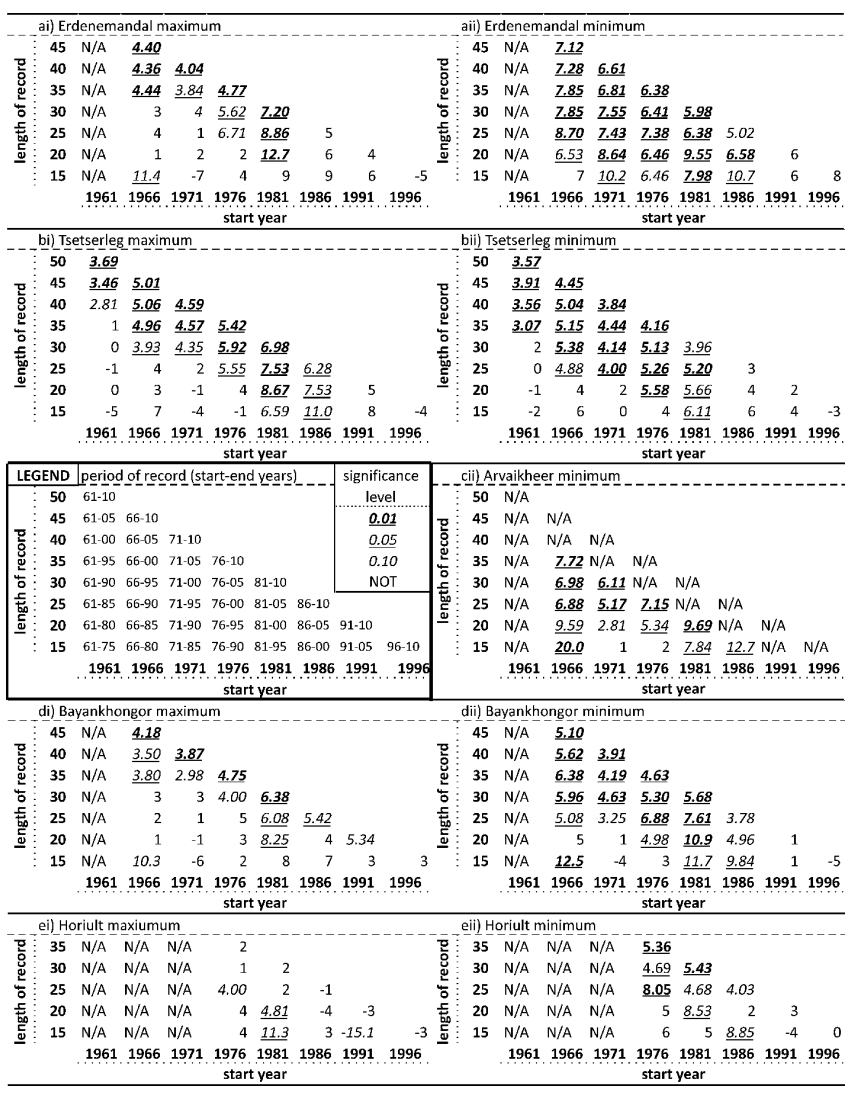


The statistically significant rates of change at the 0.001 to 0.1 levels for each station varied based on the period of record analyzed. For Erdenemandal the greatest rate of warming was for the 15 year period from 1971 through 1985, while the lowest rate of change was for a 25 year period from 1986 to 2010. Similarly at Tsetserleg, the highest rate of change was for a 15 year period from 1981 through 1995, while the lowest rate of change was a 35 year period from 1961 to 1995 (Figure 3). Several negative rates of change were noted for the maximum temperature at all stations and at Tsetserleg, Bayankhongor and Horiult for the minimum temperature. Most of these cooling trends were for shorter periods of record ( 15 to 20 years). Only the maximum temperature at Horiult for the 15 year period from 1991 to 2005 was statistically significant at the 0.1 level. The trend decreased during that time period at a rate of 15.1 degrees per century, while it increased at a rate of 11.3 degrees per century (0.05 significance level) for the same length of record 10 years earlier (1981 to 1995).

The rate of change for Bayankhongor was highest for a 15 year period (1966 to 1980) for both the maximum and minimum temperatures, yet the lowest rate of change for that station was a 25 year period (1971 to 1995). Similarly at Horiult, the greatest significant warming of minimum temperatures was a 15 year period (1986 to 2000) while the lowest rate of change was a 25 year period starting the same year (1986 to 2010). The same patterns exist for the minimum temperatures at Arvaikheer where the highest warming was a 15 year period (1966 to 1980) and the lowest was a 20 year period (1971 to 1990).

In Arkhangai aimag, the annual minimum temperatures for 2009 and 2010 were the coolest in the decade, except 2005 (Figure $2 a$ and $2 b$ ). The average of the November through March daily maximum and minimum temperatures were the coldest on record at Tsetserleg and the fourth coldest at Erdenemandal. At the latter station 2005 was almost as cold and was the only other winter in the previous three decades that was similarly cold. At Tsetserleg only the 1968-1969 winter had more individual cold days than 2009-2010. At Erdenemandal there were more cold days in 1968-1969, 19761977, and 2004-2005 than during the winter 2009-2010. The rate of temperature increase was higher for the periods ending in 2008 compared to those ending in 2010 (Table 2). When the increase was statistically significant it was greater at Tsetserleg than Erdenemandal. For the shorter lengths of record the significance was greater for the periods up to 2008 with an additional significant length of record period (Table 2). 


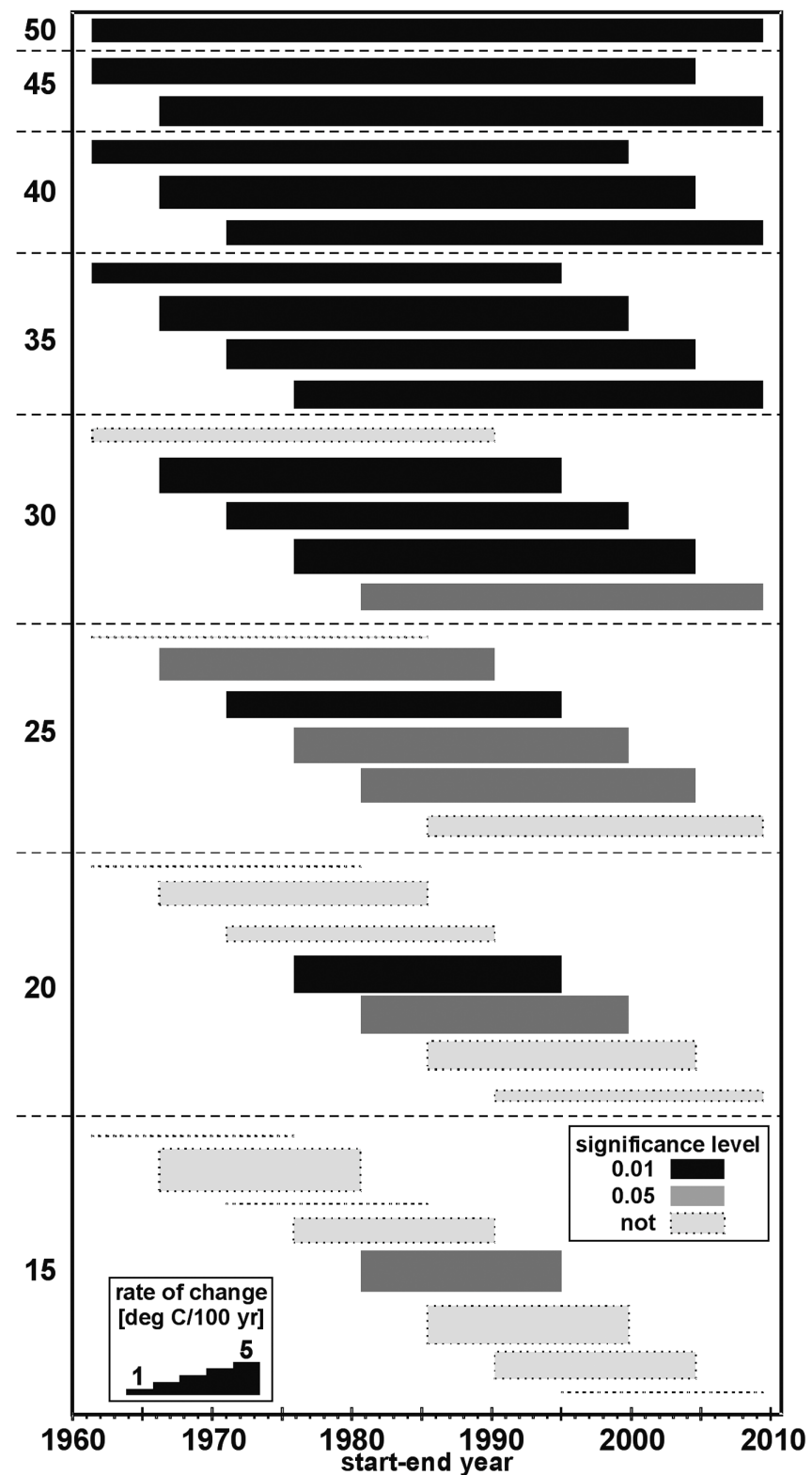

Figure 3. Graphical representation of the period and length of record calculations for the annual minimum temperature at Tsetserleg. The bar thrchness represents the rate of change. Figura 3. Representación gráfica del período y la duración de los cálculos para la temperatura mínima anual en Tsetserleg. 
Table 2. Rates of temperature change for annual i) maximum and ii) minimum temperatures in degrees Celsius per century as a function of length of record (15 to 35 years) for period ended at 2010 and at 2008. Significant rates are presented with three significant figures and are in italics for $10 \%$ significance, in italics and underlined for $5 \%$ significante, and in italics, underlined and bold for $1 \%$ significance. Non-significant rates are report with one significant figures.

Figura 2. Tasas de variación anual de la temperatura i) máximas y ii) mínimas en grados centígrados/siglo en función de la longituud de registro (de 15 a 35 años) para los períodos finalizados en 2008 y 2010. Las tasas significativas se presentan con tres cifras significativas, en cursiva para el $10 \%$ de significación, en cursiva y subrayado para el $5 \%$ de significancia, y en cursiva subrayado y en negrita para el $1 \%$ de significación. Los años sin datos se representan como N/A.

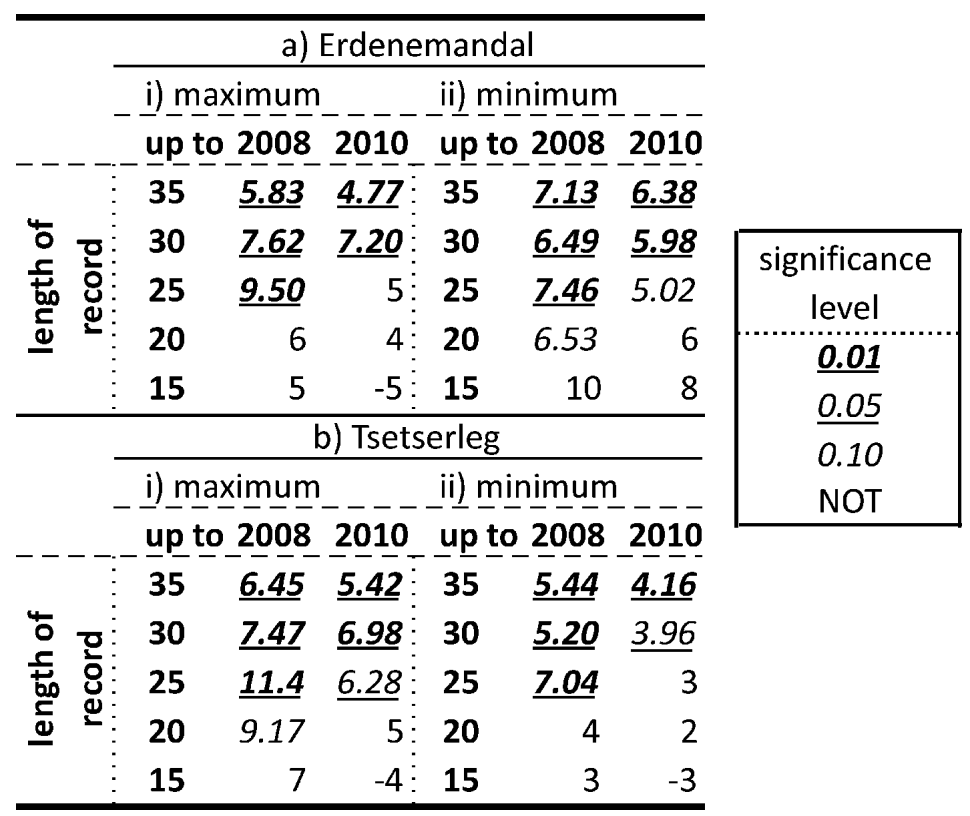

\section{Discussion}

The most significant trends were for the daily minimum temperatures (Table 1). This is consistent with other studies in semi-arid regions of the world (e.g., Pielke et al., 2002), including Mongolia, where research has documented increasing winter temperatures, warming annual minimum temperatures and decreasing numbers of cold days with minimum air temperatures below -5 degrees C (e.g. Batima et al., 2005; Jamiyansharav, 2010; Dagvadorj, 2010). Changes in minimum temperatures may have the most effect on natu- 
ral resources such as increasing or delaying plant growth in spring and changing rain/snow regimes (Yu et al., 2003).

The base period of temperature analysis used in global and regional studies varies. For the GISS (Goddard Institute for Space Studies) global analysis it is from 1951 to 1980, due to decent global data coverage and that it is a time remembered by most adults (Hansen et al., 2010). Other studies, especially those examining sites in Asia, use periods such as 1961 to 2000 or later due to the length of record available (Klein Tank et al., 2006; Marin, 2010). This analysis examined multiple time periods, due to the availability of data and the correlation to local knowledge. The data for one of the five stations (Tsetserleg) have been collected since 1961, while three started in the mid1960s (Arvaikheer only had a good minimum temperature record and it ended in the late 1990s). The Horiult station only has data from 1976 to present. Clustering of relatively higher rates of change at a high 0.001 level of significance (not shown) occurs for the 30 year period of 1966 to 1995 for four out of the five selected stations. This period is similar to those chosen for baseline temperature analysis in other studies and could be a time of reference for comparison purposes with greater amounts of statistically significant change occurring during that period.

Temperature changes are important to analyze as they influence many other natural processes. Warming (and cooling) drive processes such as evapotranspiration and the distribution and timing of precipitation events which can negatively affect pastoralists due to their reliance on naturally pastured livestock (Dagvadorj et al., 2010). Changes in minimums are more important than maximums or means in terms of biomass production, especially when warming temperatures limit moisture availability and delay green-up in the dry steppes (Yu et al., 2003). Unfortunately, specific temperature changes are difficult to quantify when recalling climate phenomena of the past from memory.

Recent herder surveys (Fassnacht et al., 2011) recorded a perception by some that the current winters are cooler than those in the past, yet one herder commented that, "winter is like fall; there is no no real winter". It is interesting to note that one of the herders who perceived cooler winters was younger than age 30. Recent winters in most areas have been much cooler than those in the 1990 's, so how far back in time a person considers may influence their perception of change. For example, the herder that commented that winter temperatures now were more like fall (implying warmer winter temperatures) was nearly 50 years old. His memory back 20 years in time could have extended back to the mid-1980's when winter temperatures were on average cooler than winters in the 2000's. 
Variability in temperature change trends may be related to larger-scale cyclicity. Periodicities are generally attributed to natural processes such as solar radiative forcing, large-scale patterns of circulation, and volcanism (Barnett et al., 2005b). In an analysis of trend and periodicity, Chen and Grasby (2009) found that the start of an instrumented climate record relative to the phase of a particular cyclic phenomenon has a strong impact on estimation of trend. Their work shows that this impact lessens with lengthening record.

Utilizing the longest record lengths results in the highest statistical significance for temperature trends. Shorter periods of record support both higher and lower, and even negative trends with much variability depending upon period of record examined (Table 1). For a majority of the sites, the shortest periods that retained significance were those of the 15 year period from 1986 to 2000. The rates of change however for these short lengths of time were usually several degrees Celsius warmer per century than those for longer lengths of record.

Station location can also influence variability in the climate change trends. Many mountainous stations are higher than 1800 metres in elevation. Connections to climatic warming with elevation have been studied and while there is no strict relation, it has been shown that the heterogeneous terrain of mountainous areas can lead to unequal climate trends especially in areas of incised valleys and flat locations (Pepin and Lundquist, 2008). The stations of Erdenemandal and Tsetserleg have the greatest number of highly statistically significant time periods. These two stations are located on the northern side of the Khangai Range, in more variable terrain than the other three stations. Bayankhongor is on the southern side of the mountain range and is also in somewhat rugged terrain. That station also has more highly significant periods than either Horiult or Arvaikheer.

Quantification of temperature trends based on a few point locations is problematic, especially related to issues of scale when interpolating or extrapolating meteorological data for use in modeling efforts (Daly, 2006). Regional averaging tends to smooth the effects of local temperature and other climate trends, and may hide important local trends (Pielke et al., 2002). For example, the average rate of highly significant temperature change in Erdenemandal is several degrees per century higher than most of the other station locations. Simple averaging of the highly significant trends of all five stations leads to a value that is several degrees lower per century than those at Erdenemandal. Perhaps the impacts of the ecological changes at Erdenemandal could be greater than those occurring at other locations with increasing minimum temperatures. This is where local knowledge of climate could be connected with regional models to test model applicability in an area (Marin, 2010). 
Though not specifically examined in this paper, memory often favors extreme events. This is likely true of extremes of climatic conditions. Analysis of temperature minimums over varying time periods relates to extremes in that minimum temperature events such as the severely cold winter of 20092010 can affect longer-term climatic trendlines (Table 2). A comparison was made between periods excluding or before the 2009-2010 dzud years (up to 2008) and including (up to 2010) the anomalously cold winter. It illustrated that removing those years increased the significance of warming temperature trends and the rate of change. Temperature trend rates in most locations became lower for shorter periods including the cold winters. Interestingly, the effect of a cold winter on change in trend from up to 2008 to up to 2010 is minimized with an increase in length of record of 30 years but then increases for 35 years (Table 2 ).

In their analysis, Chen and Grasby (2009) used mainly synthetic data to illustrate the possible implication of the sampling period on the rate and significance of change, specifically sampling within a much longer cycle so that a highly significant upward or downward trend could actually just be part of a longer term oscillation. However, an individual extreme year could greatly influence pastoralists and others directly reliant on climate. In this case, the herders throughout Mongolia were devastated by the extreme cold of 20092010 with approximately 8.5 million livestock (20\% of the livestock in Mongolia) perishing directly or indirectly from the $d z u d$, affecting approximately $28 \%$ of Mongolia's population (UN Mongolia Country Team, 2010). The herders in Bayankhongor aimag were previously affected by a $d z u d$ in 1999-2002, and were thus more prepared for the 2009-2010 extreme cold (Fernandez-Gimenez et al., 2011). Those in Arkhanagai were less prepared.

Statistically one extreme season decreased the rate of warming and for the moderate lengths of record, decreased the significance (Table 2). While different than what Chen and Grasby (2009) showed, this highlights the importance of proper analysis and interpretation of results. The implications of a changing climate, especially with an altered or possibly decreased preparedness for extremes, can be quite pronounced for those who live on the land and can provide local knowledge of change. This local knowledge can help inform and interpret environmental and climate change (see Alexander et al., 2011 for examples).

Changing minimum temperatures can affect production of vegetation needed by livestock, changes to water supplies, and even a change in the amount and type of clothing needed to survive (Yu et al., 2003; Batima et al., 2005; Angerer et al., 2008; Fassnacht et al., 2011). Large-scale regional analyses and models are useful for national-level climate change mitigation and adaptability planning (Dagvadorj et al., 2010), but local scale conditions will likely 
dictate changes in herder behavior as evidenced by responses to climate surveys (Marin, 2010; Fassnacht et al., 2011).

\section{Conclusion}

In all cases, the most significant trends were those represented by the longest lengths of record. The most significant rates of change were not the highest or lowest rates of change at each station. The most highly significant rates of change in degrees per century were not uniform from station to station and covered a range of more than 5 degrees Celsius per century. Overall, the highest and most significant rates of change were approximately the 20 year period from 1981 to 2000, with a second clustering of significant values from 25 to 35 years in duration, starting in 1966 and extending until 1990 or 2000. This second period brackets the first cluster and may represent similar information on a longer time frame.

Increases in minimum temperatures are the most significant at a range of record lengths with a maximum of 50 years to about 30 years. A mid-range time period with higher rates of temperature change in degrees Celsius per century spanned the years from 1966 to 1995 . Herder responses to climate surveys represent conditions experienced over a range of time periods. Observations however, often correlate with the documented changing climate trends. While the greatest statistical significance is noted with the longest records, shorter periods and extremes may more accurately represent the climate variability that is mentioned when herders are asked to recall natural phenomena of the past.

\section{Acknowledgements}

This research was supported by the National Science Foundation Dynamics of Coupled Natural and Human Systems (CNH) Program (award BCS-1011801 entitled Does Community-Based Rangeland Ecosystem Management Increase Coupled Systems' Resilience to Climate Change in Mongolia?). The herder data were collected through contributions from the Center for Collaborative Conservation at Colorado State University, and the World Bank (award 7155627 entitled Understanding Resilience in Mongolian Pastoral Social-Ecological Systems: Adapting to Disaster Before, During and After the 2010 Dzud). 
DOES THE LENGTH OF STATION RECORD INFLUENCE THE PERCEIVED WARMING TREND

\section{References}

Alexander, C., Bynum, N., Johnson, E., King, U., Mustonen, T. \& Neofotis, P., 2011. Linking Indigenous and Scientific Knowledge of Climate Change. Bio Science, 61(6): 477-484.

Angerer, J., Han, G., Fujisaki, I. \& Havstad, K., 2008. Climate change and ecosystems of Asia with emphasis on Inner Mongolia and Mongolia. Rangelands, 30(3): 46-51.

Barnett, T. P., Adam, J. C., \& Lettenmaier, D. P., 2005a. Potential impacts of a warming climate on water availability in snow-dominated regions. Nature, 438(7066): 303-309.

Barnett, T., Zwiers, F., Hegerl, G., Allen, M., Gillett, N. \& Hasselmann, K., 2005b. Detecting and Attributing External Influences on the Climate System: A Review of Recent Advances. Journal of Climate, 18(9): 1291-1314.

Batima, P., Natsagdorj, L., Gombluudev, P., \& Erdenetsetseg, B., 2005. Observed Climate Change in Mongolia, Assessments of Impacts and Adaptations to Climate Change (AIACC) Working Paper No. 12, 120-129, Ulaanbaatar, Mongolia.

Begzsuren, S., Ellis, J.E., Ojima, D.S., Coughenour, M.B., \& Chuluun, T., 2004. Livestock responses to droughts and severe winter weather in the Gobi Three Beauty National Park, Mongolia.Journal of Arid Environments, 59: 785-796.

Chen, Z. \& Grasby, S., 2009. Impact of Decadal and Century-Scale Oscillations on Hydroclimate Trend Analyses. Journal of Hydrology, 365(1-2): 122-133.

Dagvadorj, D., 2010. Mongolia Second National Communication, Under the United Nations Framework on Climate Change, Ministry of Nature, Environment, and Tourism, 160 pp., Ulaanbataar, Mongolia.

Daly, C., 2006. Guidelines for assessing the suitability of spatial climate data sets. International Journal of Climatology, 26: 707-721.

Fassnacht, S. R., Sukh, T., Fernandez-Gimenez, M., Batbuyan B., Venable, N. B. H., Laituri, M., \& Adyabadam, G., 2011. Local understanding of hydroclimatic changes in Mongolia. Cold Region Hydrology in a Changing Climate (Proceedings of symposium H02 held during IUGG2011 in Melbourne, Australia, July 2011), IAHS Publ. 346, 120-129.

Fernández-Giménez, M., Batbuyan B. \& Batkhishig B., 2011. Understanding Resilience in Mongolian Pastoral Social-ecological Systems, Adapting to Disaster, Before, During, and After the 2010 Dzud-Year 1 Report. Colorado State University \& The Center For Nomadic Pastoralism Studies, 119 pp., Fort Collins, Colorado, USA.

Gilbert, R. O., 1987. Statistical Methods for Environmental Pollution Monitoring. John Wiley \& Sons, New York, 320 pp. 
Hansen, J., Ruedy, R., Sato, M., \& Lo, K., 2010. Global Surface Temperature Change. Reviews of Geophysics, 48(4): RG4004.

Jamiyansharav, K., 2010. Long-term analysis and appropriate metrics of climate change in Mongolia. Unpublished PhD Dissertation, Graduate Degree Program in Ecology, Colorado State University, 135 pp., Fort Collins, Colorado, USA.

Klein Tank, A. M. G., Peterson, T. C., Quadir, D. A., Dorji, S., Zou, X., Tang, H., 2006. Changes in daily temperature and precipitation extremes in central and south Asia. Journal of Geophysical Research, 111, D16105.

Marin, A., 2010. Rider under storms: Contributions of nomadic herder's observations to analyzing climate change in Mongolia. Global Environmental Change, 20: 162-176.

Pepín, N. C. \& Lundquist, J. D., 2008. Temperature trends at high elevations: Patterns across the globe. Geophysical Research Letters, 35, L14701.

Pielke SR, R. A., Stohlgren, T., Schell, L., Parton, W., Doesken, N. \& Redmond, K., 2002. Problems in evaluating regional and local trends in temperature: an example from eastern Colorado, USA. International Journal of Climatology, 22(4): 421-434.

Solomon, S., Qin, D., Manning, M., Chen, Z., Marquis, M., Averyt, K. B., Tignor, M., \& Miller, H. L., eds., 2007. Climate Change 2007: The Physical Science Basis. Contribution of Working Group I to the Fourth Assessment Report of the Intergovernmental Panel on Climate Change. Cambridge University Press, 237-383, Cambridge, United Kingdom.

UN Mongolia Country Team, 2010. Mongolian Dzud Appeal. United National Development Programme, Office for the Coordination of Humanitarian Affairs, Consolidated Appeal, 53pp.

Yu, F., Price, K. P., Ellis, J. \& Shi, P. 2003. Response of seasonal vegetation development to climatic variations in eastern central Asia. Remote Sensing of the Environment, 87(1):42-54. 